\title{
VERTICAL COMMUNICATION ON ACHIEVEMENT MOTIVATION AND SKILLS: A STUDY OF EMPLOYEE'S PERSPECTIVE FROM A MULTI-LEVEL MARKETING COMPANY IN BANDUNG, INDONESIA
}

\author{
R. Rahadian Arby \\ Sekolah Tinggi Ilmu Ekonomi, Pasundan, Bandung, Indonesia. \\ E-mail: arby@stiepas.ac.id
}

\begin{abstract}
This study explores the communication aspect further, namely vertical communication related to achievement motivation and skills of employees who work in multi-level marketing companies. The researcher used the SEM PLS analysis technique to determine the effect of vertical communication on achievement motivation and its implications for improving employee skills. The research data use employees who work in multi-level marketing companies in the city of Bandung as many as 53 employees. The study results indicate that there is a significant effect of vertical communication on achievement motivation and has implications for increasing employee skills by 0.177 and 0.610 . Furthermore, the study results indicate that more effective vertical communication can increase employee achievement motivation, which can improve employee skills in completing the tasks and responsibilities that the company has given.
\end{abstract}

Keywords: vertical communication, achievement motivation, skills.

\section{INTRODUCTION}

Companies with a Multi-Level Marketing (MLM) foundation, which used only to operate offline, have started venturing into online marketing. Even member registration, which used to be done manually, has now turned entirely automatic, done with a machine system. At the same time, offline MLM activities are only limited to seminars or advertisements through print media. Therefore, there are many advantages that an MLM company gets by using an online system.

With the online system, members can access it from anywhere-also, members who join come from the MLM company that is located. But members from various regions can also join here. Between upline and downline members also have never met face to face. If 
we listen to this, it can be said that the development of Multi-Level Marketing in Indonesia is overgrowing accompanied by technological advances.

Online promotion is also now very intensively carried out by MLM companies. But, of course, the target to be achieved is a broader network and market. If we look at search engines with MLM keywords, there are more than 5 million search results. You can also see that for now, and many MLM companies already have their support websites. Not just information about the company, on the website members, can access bonus or commission information.

In general, MLM players do prospecting in the wrong way. Every time they find a prospect, they immediately give a presentation explaining how great the MLM they are involved in is, how prosperous the company is, how good the products are sold or how big the bonuses can be generated online and offline. If you see MLM ads circulating on the internet today, everyone is competing to say that MLM is the best. The best product, the best bonus compensation, the best company, and so on

In practice, communication and motivation are interrelated. (Foster \& Sidharta, 2019) Communication plays a vital role in organizations. Communication helps complete all the essential functions of management, namely planning, organizing, directing, and controlling, to achieve its goals and compete with others. (Suryadana \& Sidharta, 2019) Communication is how a system is established, maintained, and altered utilizing shared signals that operate according to rules. Communication is a process by which a system is established, maintained, and modified to ensure that the signals sent and received are carried out following the rules whose purpose is to work and perform according to the standards set by the organization. For that, managers must be able to motivate them. Yet it's easy to say, hard to implement. Motivation is not a simple thing to practice because it involves various disciplines. Failure to motivate could be due to a weakness in communicating with employees, which is reflected, among other things, by the manager's attitude. (Kalogiannidis, 2020)

Many communication activities are unpleasant because the communicating parties, in this case, the employee, do not understand what the manager means. (Yue, Men \& Ferguson, 2019) As a result, the employees as the recipients of the message have no or less motivation. Therefore, managers need skills to understand and create conditions in which all team leaders work teams can be motivated. Because it is inevitable that motivated employees are usually energetic and enthusiastic in doing something consistently and actively looking for roles with greater responsibility and are not afraid of challenges and even motivated to overcome them. (Diamantidis \& Chatzoglou, 2019) Even more interesting; usually, employees who are already highly motivated can also inspire other colleagues and lead them to higher achievements. And usually, those who have the motivation and can communicate well and are flexible in the association.

The effectiveness of organizational communication is the process of delivering messages or information from one person to another within the organization's scope, thereby causing an effect or influence on his behavior. (Yue, Men \& Ferguson, 2019) The effectiveness of organizational communication is the success of a communicator in delivering information, including conveying messages, receiving messages, providing 
feedback to influence the attitudes or behavior of others, establishing good relationships, and creating understanding to achieve common goals. (Bucăţa \& Rizescu, 2017) Communication is a relationship that occurs in the organization, both between individuals, organizational units, and the organization as a whole, in a successful manner that can encourage or motivate employees. (Kalogiannidis, 2020)

Skill is something that allows an individual to do a good job. (Jehow, Gikandi \& Mwencha, 2018) Good skills need to be possessed by employees in completing the tasks assigned to them. This skill refers to the individual's ability to maximize his ability to complete a specific task. (Ibrahim, Boerhannoeddin \& Bakare, 2017) To improve employee skills, there needs to be encouragement from the organization to achieve the targets that have been set. To encourage motivation, effective direction is needed using existing communication channels in the organization. In this study, vertical communication.

A pre-survey at a multi-level marketing company in Bandung indicates that there is still insufficient achievement motivation and employee skills, which is thought to be caused by the lack of effective communication between superiors and subordinates.

Based on the existing problems, the researchers formulated the problem of how much influence vertical communication has on achievement motivation and employee skills. While the purpose of this study is to determine the magnitude of the effect of vertical communication on achievement motivation and employee skills.

\section{METHOD}

The research method used in this study used a survey approach. The survey was conducted at one of the multi-level marketing companies in Bandung. The respondents who are willing to participate in the study are 53 employees. The research starts from a preliminary study, namely identifying the problem, making a frame of mind, and researching hypotheses. The following process is researching by determining the population and sampling used in data collection, conducting research trials to determine the validity of the data, and then analyzing it according to the research objectives. From the data obtained, conclusions can be drawn, following the problem under study or not.

In this research, the research variables are vertical communication, achievement motivation, and skills. The measurement of vertical communication is information about how to do work, the rationale for doing work, and information about organizational policies and practices. Indicators for measuring achievement motivation are job completion, best work results, leaders' recognition, and colleagues' recognition. While the indicators for measuring employee skills are the ability to carry out tasks, the ability to train mentally, think analytically, and think conceptually.

After the data was collected, the researchers tested the validity and reliability of the research instrument. Then after the research instrument is valid and reliable, the next step 
is to analyze the data using a non-parametric PLS-SEM approach and testing data using SmartPLS 3.

\section{RESULTS AND DISCUSSION}

After the data was collected, the researchers tested the validity and reliability of the research instrument data. The results of the analysis of validity and reliability can be seen in Table 1 below:

Tabel 1. Test result

\begin{tabular}{|l|c|c|c|}
\hline \multirow{2}{*}{ Instrument } & \multicolumn{3}{c|}{ Outer Loading } \\
\cline { 2 - 4 } & Communication & Achievement & Skill \\
\hline Comm1 & 0,828 & & \\
\hline Comm2 & 0,684 & & \\
\hline Comm3 & 0,761 & & \\
\hline Comm4 & 0,518 & 0,723 & \\
\hline Ach1 & & 0,678 & \\
\hline Ach2 & & 0,727 & \\
\hline Ach3 & & 0,559 & 0,610 \\
\hline Ach4 & & 0,592 & 0,773 \\
\hline Ach5 & & 0,702 & 0,776 \\
\hline Ach6 & & 0,543 & 0,746 \\
\hline Ach7 & & & 0,703 \\
\hline Skill1 & & & 0,638 \\
\hline Skill2 & & & 0,768 \\
\hline Skill3 & & & Average Variance \\
\hline Skill4 & & & Extracted (AVE) \\
\hline Skill5 & & & 0,523 \\
\hline Skill6 & & 0,835 & 0,577 \\
\hline Skill7 & & 0,881 & 0,587 \\
\hline & & & \\
\hline Communication & 0,772 & & \\
\hline Achievement & 0,762 & & \\
\hline Skill & 0,843 & & \\
\hline
\end{tabular}

The results of the calculation of validity indicate that the correlation between the vertical constructs of communication is above 0.5 , as well as achievement motivation and skills. The results of the reliability calculation show the vertical communication construct, achievement motivation, and skills $>0.7$ and the AVE value $>0.5$. So from the calculation, as shown in Table 1, indicates that the research instrument is valid and 
reliable. Furthermore, the path analysis calculation shows that the research construct is significant, as shown in Table 2 below.

Table 2. Data analysis results

\begin{tabular}{|l|c|c|c|}
\hline Path & B & P Value & Result \\
\hline $\begin{array}{l}\text { Communication } \\
\text { Achievement }\end{array}$ & 0,420 & 0,000 & Significant \\
\hline Achievement > Skill & 0,781 & 0,000 & Significant \\
\hline & R Square & P Value & Result \\
\hline Achievement & 0,177 & 0,000 & Significant \\
\hline Skill & 0,610 & 0,000 & Significant \\
\hline & \multicolumn{3}{|c|}{ R Square Adjusted } \\
\hline Achievement & \multicolumn{3}{|c|}{0,160} \\
\hline Skill & 0,602 \\
\hline
\end{tabular}

The results of the variation of the research instrument show that there are eight factors formed from 25 statement items with a total value of the variation of $63.54 \%$. Therefore, the calculation results indicate that $63.54 \%$ of the items can explain the research variables. Furthermore, the results of the component matrix can see in table 3 below.

Table 2 shows that Communication> Achievement has a $B$ value of 0.420 with a $p$ value of 0.000 and Achievement $>$ Skill with a $B$ value of 0.781 and a p-value of 0.000 . $R$ square Achievement and Skill are 0.177 and 0.610, respectively, with a p-value of 0.000. The calculation results indicate that the effect of directional Communication on achievement motivation is significant, as well as the influence of achievement motivation on significant skills. The calculation results can be described as shown in Figure 1 below.

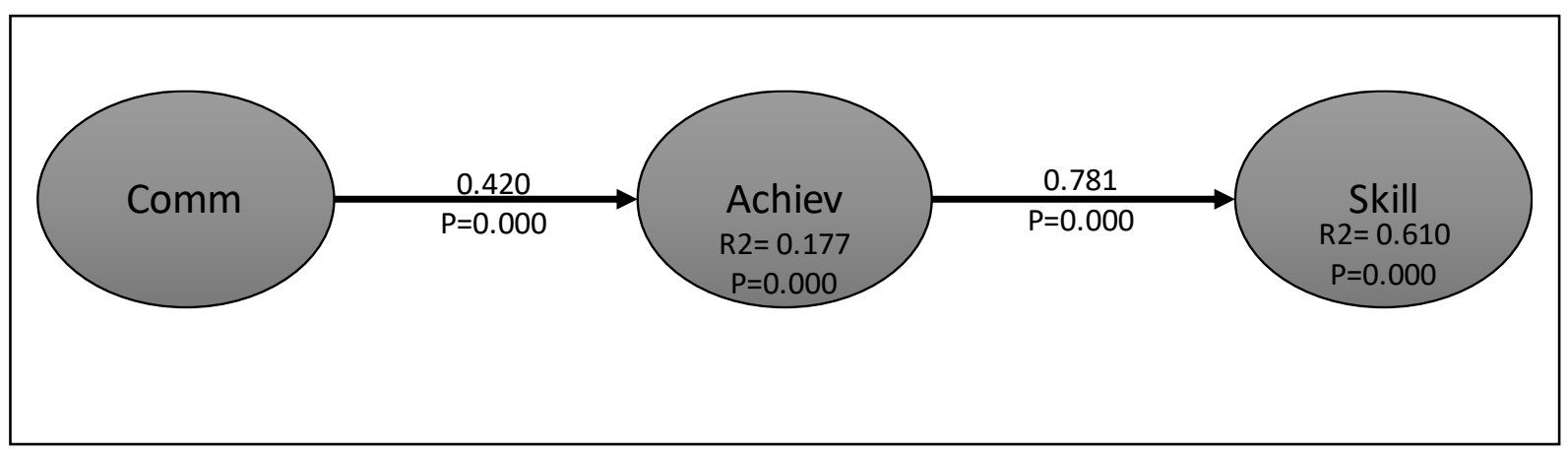

Figure 1. The results of the calculation of the research model

Based on the calculations shown in Table 2 and Figure 1, it can be seen that there is a significant effect of vertical communication on achievement motivation and has significant implications for skills.

Communication, in general, is quite good, this can be seen from the downward communication dimension which is quite good, it can be seen from the involvement of the team leaders who are already quite good where the team leaders play an active role and 
always try to be involved in every event held by the agency other than the team The leader also looks critical in building their organization where every shortcoming is always tried to be criticized wisely by each team leader. Bucăţa \& Rizescu (2017) show the vital role of communication in management where the effectiveness of good communication will increase employee motivation to work better. Although some can look like skills in making financial statements, others like negotiating skills are difficult to identify. While skills that can improve performance are hidden competencies. People with high competence always have a strong drive that can shape characteristics in themselves and build one's personality to always complete work correctly and follow existing work standards. Locke \& Schattke (2019) clarified intrinsic and extrinsic motivation, which is difficult to see. Therefore, there is a need for effective communication to increase individual hidden motivation.

Furthermore, Idowu (2017) suggests that increasing employee motivation requires effective communication and collaboration between individuals in the organization. The need for achievement is the need to do something better. People with high achievement motives will think more about doing a better job or the obstacles they might face. For that, he will make a plan with careful calculations. Expertise tends to be visible and relatively on the surface as one of the characteristics possessed by humans. At the same time, self-concept, trait, and motive are more hidden, deeper competencies. They are at the central point of the individual's personality.

Achievement Orientation ( $\mathrm{ACH})$, an orientation that emphasizes better work results. Concern for order, quality, and accuracy, initiative, and information-seeking orientation. Ciobanu, A., Androniceanu, A., \& Lazaroiu, G. (2019) identified that building a sound human resources system creates effective communication that can increase employees' pro-active attitudes and behaviors in the organization. Similarly, Sidharta, Priadana \& Affandi (2019) revealed that the pro-active behavior of employees could be improved by paying attention to human capital, with achievement motivation will have an impact on increasing the dynamic behavior of individuals in the organization.

Skills are relatively easy to develop. Training programs are an excellent way to ensure human resource capabilities, while the motive for competence and character is in the personality iceberg. Hence, it is not easy to assess and develop. One of the most effective ways is to choose these characteristics in the selection process. The staff concept lies between the two. Manik \& Sidharta (2017) show a close relationship between achievement motivation and abilities and skills, where achievement motivation is the fundamental motivation of individuals to improve their abilities and skills to produce good employee performance. The results of the meta-analysis research conducted by Van Iddekinge, Aguinis, Mackey \& DeOrtentiis (2018) show that achievement motivation is an individual motivation that can improve individual skills, which have implications for individual performance. Rodriguez \& Walters (2017) reveal the vital role of improving skills to produce superior individual performance. 


\section{CONCLUSION}

The study results illustrate that overall achievement motivation can be described as adequate. However, there are still not good aspects, namely trying always to complete all work well and work optimally to get the best work results. Skills are pretty good, but there are still inadequate aspects, namely the lack of analysis of the work that has been done and the lack of carrying out actions following the abilities and expertise possessed. Communication is adequate, but there are still no good aspects. Namely, problems are solved together. Subordinates in submitting questions can be adequately answered and wisely by superiors.

The study results indicate that more effective vertical communication can increase employee achievement motivation, which can improve employee skills in completing the tasks and responsibilities that the company has given.

To increase achievement motivation by increasing motivation where interactions must be further optimized, the leader must continually encourage team leaders to improve their abilities, so that team leaders do not feel satisfied with their abilities. Improve team leader skills and apply to the team leader that the tasks or work carried out must be re-analyzed and re-examined so that small mistakes do not occur again. Besides that, it is also necessary to increase the team leader's confidence so that the team leader does not quickly feel hopeless when facing hard work. Communication can be improved by consistently applying to each team leader to overcome problems so that there are no more complex problems to solve. There will be no long debates that impact conflicts between team leaders in a good organization.

\section{REFERENCES}

Bucăţa, G., \& Rizescu, A. M. (2017). The role of communication in enhancing work effectiveness of an organization. Land Forces Academy Review, 22(1), 49-57.

Ciobanu, A., Androniceanu, A., \& Lazaroiu, G. (2019). An integrated psychosociological perspective on public employees' motivation and performance. Frontiers in Psychology, 10, 36.

Diamantidis, A. D., \& Chatzoglou, P. (2019). Factors affecting employee performance: an empirical approach. International Journal of Productivity and Performance Management, 68(1), 171-193. https://doi.org/10.1108/IJPPM-01-2018-0012

Foster, B., \& Sidharta, I. (2019). Dasar-Dasar Manajemen. Yogyakarta: Diandra Kreatif.

Ibrahim, R., Boerhannoeddin, A., \& Bakare, K. K. (2017). The effect of soft skills and training methodology on employee performance. European Journal of Training and Development, 41(4), 388-406. https://doi.org/10.1108/EJTD-08-2016-0066 
Idowu, A. (2017). Effectiveness of performance appraisal system and its effect on employee motivation. Nile Journal of Business and Economics, 3(5), 15-39.

Jehow, F. A., Gikandi, J., \& Mwencha, P. (2018). Effect of training and leadership skills on employee performance in devolved governments in Kenya: A case of Wajir County. European Journal of Business and Strategic Management, 3(4), 87-104.

Kalogiannidis, S. (2020). Impact of Effective Business Communication on Employee Performance. European Journal of Business and Management Research, 5(6), 16. https://doi.org/10.24018/ejbmr.2020.5.6.631

Locke, E. A., \& Schattke, K. (2019). Intrinsic and extrinsic motivation: Time for expansion and clarification. Motivation Science, 5(4), 277-290.

Manik, E., \& Sidharta, I. (2017). The Impact of Motivation, Ability, Role Perception on Employee Performance and Situational Factor as Moderating Variable of Public Agency in Bandung, Indonesia. International Journal of Management Science and Business Administration, 3(4), 65-73.

Rodriguez, J., \& Walters, K. (2017). The importance of training and development in employee performance and evaluation. World Wide Journal of Multidisciplinary Research and Development, 3(10), 206-212.

Sidharta, I., Priadana, M. S., \& Affandi, A. (2019). Innovative behavior: the study of intellectual capital effect on creative fashion industry in Bandung, Indonesia. Problems and Perspectives in Management, 17(4), 404-415. doi:10.21511/ppm.17(4).2019.33

Suryadana, M. L., \& Sidharta, I. (2019). Manajemen Sumber Daya Manusia Industri Hospitality. Yogyakarta: Diandra Kreatif.

Van Iddekinge, C. H., Aguinis, H., Mackey, J. D., \& DeOrtentiis, P. S. (2018). A metaanalysis of the interactive, additive, and relative effects of cognitive ability and motivation on performance. Journal of Management, 44(1), 249-279.

Yue, C. A., Men, L. R., \& Ferguson, M. A. (2019). Bridging transformational leadership, transparent communication, and employee openness to change: The mediating role of trust. Public relations review, 45(3), 101779. https://doi.org/10.1016/j.pubrev.2019.04.012 